\title{
SISTEM PEREKONOMIAN NEGARA-NEGARA DI DUNIA
}

\author{
Dicky Sumarsono \\ Sekolah Tinggi Ilmu Ekonomi AAS Surakarta \\ dicki.stieaas@gmail.com
}

\begin{abstract}
This study aims to look at the existing economic system in this world, both socialist economic system, capitalist economic system, and Islamic economic system. The research method used is literature study method. The results of the study indicate that the socialist economic system, the economic system in which the government has a very big role in managing the wheels of the economy from upstream to downstream in the economic chain in society, and this economic system has not existed or not developed since the collapse of the soviet union. While the capitalist economic system, the economic system gives people the freedom to own wealth, and this system also dominates the economic systems used by countries in this world. Then the Islamic economic system until recently is a concept that will be an alternative to the economic system that prosper with a lot of learning also from the two existing economic system, namely the capitalist economic system and socialist economic system, of course take things positive of both as long as it is not against the Islamic Shari'ah that comes from the sources of Islamic law especially the Qur'an and al-Hadis.
\end{abstract}

Keywords: system, economy country, world

\section{PENDAHULUAN}

Sistem perkonomian oleh suatu negara atau pemerintah digunakan untuk memecahkan berbagai macam permasalahan yang berkaitan dengan ekonomi yang dialaminya, tentunya agar permasalahan-permasalahan yang berkaitan dengan ekonomi itu dapat teratasi dan terselesaikan, justru jangan sampai dengan ada dan munculnya suatu sistem ekonomi malah menambah atau bahkan memperparah masalah ekonomi suatu negara yang semakin membebani.

Pengertian sistem ekonomi menurut Gilarso (1992: 486), sistem ekonomi dapat diartikan sebagai keseluruhan tata cara untuk mengoordinasikan perilaku masyarakat (para produse, konsumen, pemerintah, bank, dan sebagainya) dalam menjalankan kegiatan ekonomi (produksi, distribusi, konsumsi, investasi, dan sebagainya) sehingga terbentuk satu kesatuan yang teratur dan dinamis, dan kekacauan dapat dihindari. Sedangkan menurut Dumatry (1996) : Pengertian sistem ekonomi menurut Dumatry adalah suatu sistem yang mengatur dan terjalin hubungan ekonomi antar sesama manusia dengan seperangkat kelembagaan dalam suatu ketahanan.

Jika ditinjau, sampai dari dahulu saat sekarang dapat dikatan belum ada sistem ekonomi yang sempurna yang menjadi solusi dalam rangka menyelesaikan persoalan bangsa dan negara khususnya dalam hal pemerataan dan keadilan bagi masyarakat secara luas, sebagaimana yang dicita-citakan oleh sistem ekonomi Islam (Tho'in, 2015). Jika menengok sejarah, sistem ekonomi negaranegara di dunia ini secara garis besar telah didominasi oleh dua sistem ekonomi, yaitu sistem ekonomi sosialis dan sistem ekonomi kapitalis. Sistem ekonomi 
kapitalis dalam menjalankan berbagai kegiatannya bersandar kepada pemilikan atas harta benda secara pribadi terhadap alat-alat produksi yang ia kuasai, kegiatan distribusi yang ia jalankan, maupun pertukaran atas barang-barang yang dikuasainya. Sehingga tiga macam kepemilikian itulah yang berada penuh di tangan swasta atau pribadi dalam sistem ekonomi kapitalis. Sistem ekonomi kapitalis inilah yang dalam perkembangannnya mendominasi secara keseluruhan dari system-sistem ekonomi yang ada sampai saat ini. Dalam sistem ekonomi kapitalis dimana suatu produksi serta kegiatan perdagangannya lebih dominan dilakukan bersifat pribadi-pribadi atau perseorangan. Individu serta perusahaan atau bahkan melalui badan usaha swasta atau korporasi, berupa bantuan modal yang sebelumnya telah diakumulasikan, tetapi yang lebih banyak terjadi dengan menggunakan modal usaha dari pinjaman berbunga, mendapatkan keuntungan atau laba serta membangun suatu kerajaan untuk diri mereka sendiri dengan jalan mempekerjakan orang banyak dengan memberikan imbalan upah (Chaudhry, 2012: 355-356) Sedangkan sistem ekonomi yang kedua, adalah sistem ekonomi sosialis. Sistem ini berkebalikan dengan sistem ekonomi kapitalis. Dimana, di dalam sistem ekonomi ini kegiatankegiatan ekonominya mulai dari perencanaan, pelaksanaan, serta pengawasan dilakukan oleh pemerintah secara terpusat. Sehingga setiap individu tidak berhak atas kekayaan yang dimilikinya, karena alat-alat produksi, kegiatan distribusi, maupun pertukaran dilakukan oleh pemerintah dengan tujuan kesejahteraan masyarakat bersama. Kedua sistem ekonomi tersebut tentunya memiliki kelebihan dan kekurangan masing-masing. Hal yang paling mendasar dari kedua sistem ini adalah masih adanya aspek kedholiman. Pada sistem ekonomi kapitalis, masyarakat kecil selaku buruh mendapatkan perlakukan semena-mena dari pemilik modal, terutama kebijakan upah dan lain sebagainya. Sedangkan pada sistem ekonomi sosialis, hakhak individu yang seharusnya dapat ia miliki tidak diperbolehkan oleh pemerintah. Hal tersebut mendorong untuk terwujudnya konsep sistem ekonomi yang baru (di antara kapitalis dan sosialis). Sehingga para pemilik modal tetap dapat menjalankan usahanya tanpa merugikan buruh maupun orang lain, dan kepemilikan kekayaan pribadi tetap diakui dalam batasbatas yang ditentukan. Dengan demikian, adanya ekonomi Islam diharapkan dapat menjadi solusi dari permasalahan yang ada, sebagai sistem ekonomi jalan tengah. Sehingga, harapan terwujudnya sistem ekonomi yang berkeadilan menuju kemakmuran dan pemerataan "baldatun thayyibatun wa rabbun ghafur" dapat tercipta. Penelitian ini akan mencoba mencari konsep ekonomi jalan tengah, dalam hal ini yaitu konsep sistem ekonomi Islam sebagai jalan tengah yang berdiri diantara sistem ekonomi kapitalis dan sistem ekonomi sosialis dengan melihat kebaikan dan kelemahan dari masingmasing sistem tersebut, kemudian kebaikan-kebaikan kedua sistem ekonomi tersebut (kapitalis dan sosialis) dipadukan dan digunakan sebagai konsep ekonomi Islam selama kebaikan tersebut sejalan pula dengan ketentuan-ketentuan syariah Islam, serta mencari tantangan yang menjadi hambatan dari ekonomi Islam itu sendiri, agar perekonomian ummat Islam juga dapat berkembang pesat seperti pada 
masa-masa kejayaan Islam di masa lalu, baik saat zaman Nabi maupun sahabat.

\section{METODOLOGI PENELITIAN}

Jenis penelitian ini merupakan penelitian kualitatif dengan menggunakan metode studi pustaka sebagai metodologi penyelesaiannya. Sehingga konsep ekonomi Islam yang diharapkan dapat terbangun melalui teori-teori yang sudah ada sebelumnya.

\section{PEMBAHASAN}

\section{Sistem Ekonomi Kapitalis}

Kapitalisme adalah pandangan hidup atau suatu ideologi yang sangat berkembang, hal tersebut dibuktikan dengan banyaknya negara-negara di dunia pada saat ini menggunakan sistem ekonomi ini. Kapitalisne diartikan pandangan hidup atau ideologi karena selain sebagai suatu pandangan hidup itu sendiri, ia juga mempunyai serangkaian aturan yang harus dijalankan dalam kehidupan sehari-hari. Munculnya ideologi kapitalisme dilatar belakangi oleh pada saat agama mulai dijadikan sebagai suatu alat untuk menganiaya dan memeras rakyat oleh para kaisar atau raja-raja di Rusia dan Eropa. Hal tersebut mengakibatkan berbagai usaha serta pertentangan-pertentangan dari kalangan para cendekiawan dan para filsof. Para cendekiawan dan filosof mengadakan semacam perundingan untuk masalah tersebut. Hasil dari berbagai adanya suatu perundingan tersebut adalah sebagian dari mereka yang mengingkari adanya suatu agama. Tetapi yang lain masih mengakui agama, namun mereka menyerukan untuk tidak menghubung-hubungkan antara suatu agama dari masalah kehidupan. Akhirnya diambillah pendapat mayoritas, yang hasilnya adalah memutuskan untuk memisahkan agama dari kehidupan.
Mereka mengakui adanya agama, namun mereka mengesampingkan peran agama dalam kehidupan.

Berdasarkan beberapa hal tersebut di atas diketahui bahwa kapitalisme berdiri atas ide sekulerisme, yaitu adanya pemisahan suatu agama dari kehidupan itu sendiri. Oleh karena itu, kaidah berpikir ideologi kapitalisme adalah sekulerisme. Sehingga dalam prakteknya, kapitalisme mengusung adanya empat kebebasan yang mereka percayai sebagai suatu bagian terpenting dalam melaksanakan ideologinya itu, yaitu kebebasan untuk beragama, kebebasan untuk berpendapat sesuai dengan pemikirannya, kebebasan atas adanya hak milik, serta kebebasan pribadi atau privasi. Adanya suatu kebebasan hak milik atas harta yang dimilikinya tersebut, itulah yang kemudian memunculkan adanya suatu sistem ekonomi kapitalisme. Sistem kapitalisme yang ada, aspek moneter dan ekonomi yang paling menonjol di dalamnya. Karena nilai umum yang ada pada sistem ini adalah manfaat pada suatu materi atau kebendaan. Orang yang memiliki dan menguasai harta yang dominan atau banyaklah yang akan menguasai masyarakat serta mengatur negara sesuai dengan keinginan yang dikehendakinya. Dari adanya konsep kebebasan kepemilikan atas harta inilah yang memunculkan privatisasi harta kekayaan baik itu harta umum maupun harta kekayaan negara. Seperti yang kita lihat di negara kita tercinta ini, banyak tambang yang diperbolehkan untuk dikuasai individu atau kelompok bahkan dalam kegiatan dan penguasaannya telah dilindungi dalam undang-undang penanaman modal yang ada. Dari adanya suatu prinsip kebebasan kepemilikan yang ada pada sistem ekonomi kapitalis inilah, JURNAL AKUNTANSI DAN PAJAK VOL. 16 NO. 02, JANUARI 2016 -22 
akhirnya banyak pula kekayaan atau harta negara yang diakui individu sebagai harta miliknya.

Sistem ekonomi kapitalis menjadi sistem ekonomi yang mendominasi dari sistem ekonomi yang dipakai negaranegara saat ini. Meskipun dengan perkembangan teknologi dan informasi atau IT yang begitu dahsyat saat ini, boleh dikatakan tidak ada sistem ekonomi kapitalis murni, karena di negara-negara kapitalis lebih sosialis dibandingkan dengan negara-negara yang menggunakan sistem ekonomi sosialis itu sendiri. (Asy'arie, Disampaikan dalam Focused Group Discussion Matakuliah Sejarah Pemikiran Ekonomi Islam, Pascasarjana UIN Sunan Kalijaga, Kamis, 15 Desember 2016) Menurut Winardi (1990) Sistem ekonomi kapitalis ini, merupakan suatu sistem ekonomi di mana hak milik pribadi atas alatalat produksi, kegiatan distribusi, serta pemanfaatannya untuk mencapai laba dalam kondisi maupun situasi yang sangat kompetitif, menjadi ciri utama dalam sistem ini. Jika kita melihat sejarah, kapitalisme dibangun dari buah pemikiran tokoh ekonomi besar yaitu Adam Smith, dia merupakan tokoh dari mazhab klasik. Para ahli ekonomi dunia mayoritas sepakat bahwa hasil dari pemikiran mazhab klasik inilah yang menjadi dasar dari sistim ekonomi, yaitu sistem ekonomi kapitalis (Agustiati, 2009: 152). Dasar pemikiran teori yang dikeluarkan oleh Adam Smith ini dapat bertahan hingga terjadinya depressi ekonomi pada tahun 1929, di mana pada saat itu pemikir ekonomi lainnya, yaitu Keyness mengeluarkan gagasannya, dia tampil serta berhasil mengungkapkan sebuah teori dan gagasan bahwa sistem ekonomi yang baru dan lebih baik dapat dibangun. Pemikiran Keyness ini atau Keynesian membutuhkan adanya intervensi serta campur tangan dari pemerintah dalam menentukan kebijakankebijakan ekonomi. Hal inilah yang menjadi awal jatuhnya sistem ekonomi kapitalis saat itu, akan tetapi dengan berjalan waktu selama lebih kurang 30 tahun terjadi krisis yang besar yang melanda dunia, berupa krisis minyak dunia tepatnya pada tahun 1973, sistem ekonomi kapitalis yang jatuh kembali tampil sebagai sistem ekonomi dengan nama baru, yaitu neoliberalisme (Agustiati, 2009: 152). 1. Pilar-pilar sistem ekonomi kapitalis Sistem ekonomi kapitalis ini menyadarkan diri secara penuh kepada hal-hal di bawah ini: a. Private property atau hak milik swasta $b$. The invisibel hand atau dibina oleh tangan tak terlihat c. Idividualisme ekonomi d. Free market kompetition atau persaingan dan pasar bebas 2. Kerangka dasar sistem ekonomi kapitalis a. Kelangkaan sumbersumber ekonomi Benturan antara kebutuhan manusia yang tidak terbatas dengan terbatasnya (langkanya) barangbarang ekonomi yang tersedia dalam usaha menjembatani hal tersebut adalah dengan jalan menambah jumlah produksi barang dan jasa sebanyakbanyaknya agar kebutuhan manusia yang tidak terbatas dapat diperkecil, adanya kelangkan sumber-sumber ekonomi maka para ekonomi kapitalis melihat 3 pokok permasalahan ekonomi yang harus dipecahkan (1) Apa yang harus diproduksi dan dalam jumlah berapa? pertanyaan pertama ini secara umum menyangkut barang dan jasa yang dibutuhkan manusia, dan secara khusus menyangkut singkronisasi antara kebutuhan manusia dengan daya belinya. (2) Bagaimana sumber-sumber ekonomi (faktor-faktor produksi) yang tersedia harus dipergunakan untuk memproduksi barangbarang tersebut? jawaban permasalahan 
yang kedua ini adalah menyangkut tentang teknik produksi, yaitu bagaimana mengkombinasikan faktor-faktor produksi untuk mendapatkan output yang optimal. (3) Untuk siapa barang tersebut di produksi; atau bagaimana barang-barang tersebut di bagikan di antara warga masyarakat? jawaban atas permasalahan yang ketiga ini pakar ekonomi kapitalis menjawabnya dengan pembahasan teori harga, yaitu peranan harga dalam menentukan produksi-komsumsidistribusi (Boediono, 1993) Meskipun jawaban permasalahan di atas pada akhirnya harus berbenturan dengan tingkat permintaan konsumen, di mana tingkat permintaan konsumen dipengaruhi oleh banyak faktor, sehingga tingkat produksi secara riil bukanlah produksi sebanyak-banyaknya karena dapat mengakibatkan inefisiensi ekonomi dan ketidak seimbangan pasar (market disequilibrium) akan tetapi philosopi pemecahan masalah (problem solving) ekonomi dengan cara seperti ini menentukan bagaimana sistem ekonomi kapitalis melihat hakekat permasalahan ekonomi. Dengan cara pandang seperti ini, maka bagi sistem ekonomi kapitalis, solusi ekonomi yang harus ditempuh secara mikro adalah peningkatan produksi sebanyak-banyaknya, dan secara makro mengejar pertumbuhan ekonomi setinggitingginya. b. Pandangan tentang nilai barang Dalam sistem ekonomi kapitalis, nilai merupakan sesuatu yang sangat penting. Karena nilai merupakan suatu sarana untuk melihat faedah atau kegunaan suatu barang dan jasa, juga untuk menentukan kemampuan produsen dan konsumen. Ada dua kategori tentang nilai barang dan jasa yaitu yang berkaitan dengan nilai kegunaan suatu barang bagi individu yang disebut nilai guna (utility value), dan yang berkaitan dengan nilai suatu barang terhadap barang lainnya disebut nilai tukar (exchange value). c. Peranan harga dalam sistem ekonomi kapitalis. Harga di dalam sistem ekonomi kapitalis mempunyai peranan dalam kegiatan produksi, kegiatan konsumsi, serta kegiatan distribusi melalui struktur harga. 1) Peranan harga dalam kegiatan produksi Peranan harga dalam bidang produksi, harga menentukan siapa saja produsen yang boleh masuk dalam area produksi dan siapa saja yang tidak boleh masuk atau keluar dari area produksi. Struktur harga dengan sendirinya akan megatur dan menyaring produsen berdasarkan tingkat kemampuan produsen dalam menanggung biaya produksi yang meliputi biaya pengadaan barang kemudian struktur harga juga akan menyaring para produsen yang tetap bertahan di area produksi, ketika beban biaya produksi masih dapat ditanggung produsen yang mungkin disebabkan oleh masih adanya persediaan modal yang dimiliki produsen tersebut, atau karena kemampuan inovasi produsen dalam mengelola manajemen yang efisien dan kwalitas produksi yang memenuhi selera pasar, atau juga disebabkan karena produsen tersebut melakukan praktek tidak fair dengan merusak harga pasar, monopoli atau praktek-praktek curang yang membuat produsen saingannya terlempar dari area produksi. Mekanisme persaigan ekonomi seperti ini dengan menjadikan harga sebagai alat yang megendalikan produsen dalam area produksi, maka kepemilikan produksi dalam sistem ekonomi kapitalis ditentukan oleh kekuatan modal yang dimiliki para produsen, sehingga rakyat lemah yang tidak memiliki kemampuan modal akan terlempar dari area produksi dan akhirya menjadi masyarakat pinggiran (marginal society). 2) Peranan harga dalam 
kegiatan konsumsi Peranan harga dalam kegiatan konsumsi, harga merupakan alat pengendali yang menentukan kemampuan konsumen dalam memenuhi berbagai kebutuhan dan keinginannya. Harga merupakan mekanisme yang mempersilahkan orang-orang mampu untuk membeli kekayaan yang mereka kehendaki dengan uang yang mereka miliki. Harga pula yang membuat hidup orang pas-pasan, atau harga merupakan mekanisme yang menentukan siapa saja orang yang berhak hidup dan siapa saja yang harus menyingkir dari kehidupan. Misalnya adalah kebijakan penghapusan subsidi perguruan tinggi oleh pemerintah yang mengakibatkan biaya pendidikan, terutama biaya pendidikan diperguruan tinggi favorit meningkat tajam sehingga sulit dijangkau oleh masyarakat golongan masyarakat menengah ke bawah. Kebijakan ini akhirnya menentukan siapa saja para pemuda Indonesia yang layak melanjutkan pendidikan ke perguruan tinggi, bahkan beberapa perguruan tinggi memberikan tempat istimewa bagi orangorang kaya melalui jalur khusus, ini tentunya tidak memberikan kesempatan yang sama pada anak bangsa untuk memiliki masa depan yang layak. 3) Peranan harga dalam kegiatan distribusi Stuktur harga sebagai titik pertemuan antara penawaran produsen dan permintaan konsumen merupakan metode distribusi dalam sistem ekonomi kapitalis. Pertemuan antara tingkat harga yang berlaku di pasar dengan keputusan konsumen untuk membeli barang dan jasa merupakan sarana penyaring mana barang yang laku dan tidak laku. Kedua keadaan tersebut memiliki konsekwensi masing-masing. Konsekwensi pertama, terhadap barang yang laku di pasaran adalah kemungkinan keuntungan yang diperoleh produsen. Pada saat produsen untung ia akan memutuskan apakah tingkat produksi (penawaran) tetap ataukah dinaikkan. Konsekwensi kedua, terhadap barang yang tidak laku di pasaran adalah kemungkinan kerugian yang dialaminya maka ia tetap melakukan produksi meskipun dengan menurunkan tingkat produksinya. Sebaliknya, ketika produsen tidak mampu lagi menanggung kerugian, maka baginya harus menghentikan produksi atau dengan kata lain menutup usahanya. Kombinasi dua konsekwensi tersebut menghasilkan atau mengubah laju produksi sebelumnya. Adapun yang dimaksud dengan laju produksi menyangkut tiga hal, yaitu barang apa saja yang diproduksi, berapa banyak diproduksi, dan untuk siapa barang tersebut diproduksi. Bagi produsen, barang yang diproduksi adalah barang dan jasa yang menghasilkan keuntungan, yakni barang yang laku di pasaran. Dari pemaparan di atas, sudah jelas bahwa dalam sistem ekonomi kapitalis memiliki kelebihan dan kekurangan yang masingmasing dapat dijelaskan. 3. Kelebihan sistem ekonomi kapitalis sebagai berikut yang dirilis oleh Amazine.coOnline Popular Knowledge Tahun 2017 adalah sebagai berikut: a. Kapitalisme mendorong pertumbuhan ekonomi dengan memfasilitasi kompetisi terbuka di pasar. b. Sistem ini menyediakan individu kesempatan lebih baik untuk meningkatkan pendapatan mereka dan dengan demikian mencapai pertumbuhan ekonomi. c. Hasil dari kapitalisme adalah sistem ekonomi yang terdesentralisasi. Faktor ini dianggap sebagai salah satu kelebihan terbesar kapitalisme. d. Dalam perekonomian yang terdesentralisasi, individu memiliki lebih banyak pilihan dalam bisnis. e. Mereka terpapar dengan kompetisi dan harus menghadapi tantangan yang berbeda serta 
dituntut menemukan solusi untuk unggul dalam kompetisi. f. Kerja keras amat dihargai dalam ekonomi kapitalis. Pengusaha yang memiliki kinerja baik dan mampu terus berinovasi akan memenangkan persaingan. g. Kapitalisme membentuk ekonomi dimana konsumen mengatur pasar. Banyak yang menganggap ini sebagai salah satu kekuatan terbesar ekonomi kapitalis. h. Sebuah pasar yang kompetitif akan merangsang inovasi dan mendorong munculnya bermacam produk dan layanan. Hal ini membuat konsumen memiliki lebih banyak pilihan serta mendorong orang untuk mencapai kebebasan finansial. 4. Kekurangan sistem ekonomi kapitalis yang dirilis oleh Amazine.co-Online Popular Knowledge Tahun 2017 adalah sebagai berikut: a. ekonomi kapitalis dapat menimbulkan persaingan tidak sehat. b. Kapitalisme membuat ekonomi yang berorientasi pada uang. Perusahaan bisnis akan melihat ekonomi dengan titik pandang materialistik. c. Profit dipandang menjadi tujuan bisnis utama dengan raksasa bisnis mengambil alih perusahaan-perusahaan kecil. d. Tenaga kerja juga dikompensasi dengan tujuan tunggal agar memiliki produktivitas lebih tinggi. e. Sebagian ekonom percaya bahwa kapitalisme memicu penipisan sumber daya alam karena dieksploitasi untuk menjaga pertumbuhan ekonomi yang berkesinambungan. f. Kapitalisme juga diyakini menyebabkan distribusi kekayaan yang tidak adil dengan kekayaan dan kekuasaan hanya dikuasai oleh segelintir orang.

\section{Sistem Ekonomi Sosialis}

Sistem Ekonomi Sosialis Sistem ekonomi ini merupakan bentuk resistensi dari sistem ekonomi sebelumnya yaitu sistem ekonomi kapitalis. Karena sistem ekonomi kapitalis dituding menjadi penyebab tidak tercapainya suatu kesejahteraan masyarakat yang merata. Sistem ekonomi sosialis merupakan kebalikan dari sistem ekonomi kapitalis, yang mana menyerahkan segala siklus ekonomi sepenuhnya kepada mekanisme pasar yang ada. Sedangkan untuk sistem ekonomi sosialis, di mana pemerintah sangat memiliki peran sangat besar di dalam mengelola roda perekonomian dari hulu hingga hilir dalam rantai perekonomian di masyarakat. Sistem ekonomi sosialis bukan berarti tidak memberikan kebebasan individu dalam kegiatan ekonomi, individu tetap diberikan kebebasan dalam melakukan aktivitas ekonomi tetapi sangat terbatas sekali, serta dengan adanya campur tangan pemerintah yang sangat besar. Pemerintah melakukan campur tangan demi terwujudnya kemakmuran masyarakat bersama, tetapi di sisi lain kepemilikan individu yang dibatasi menyebabkan kreativitas individu menurun karena semangat untuk berkarya di bayangbayangi oleh pemerintah untuk kemakmuran bersama. Karena sistem ekonomi sosialis ini memiliki pandangan bahwa suatu kemakmuran pribadi atau individu hanya dapat terwujud jika berlandaskan kemakmuran secara bersamasama. Sehingga konsekuensi yang harus dipertaruhkan ialah penguasaan dan kepemilikan atas aset-aset ekonomi maupun terhadap faktor-faktor produksi yang ada sebagian besarnya adalah kepemilikan untuk sosial. 1. Ciri-ciri sistem ekonomi sosialis a. Lebih mengutamakan kebersamaan atau kolektivitas. b. Pemerintah memiliki peran sangat besar c. Sifat manusia dalam sistem ini ditentukan oleh pola produksi d. Hak milik individu tidak diakui 2. Prinsip dasar JURNAL AKUNTANSI DAN PAJAK VOL. 16 NO. 02, JANUARI 2016 -26 
sistem ekonomi sosialis menurut Caporaso (2008), adalah sebagai berikut: a. Pemilikan harta oleh negara seluruh bentuk produksi dan sumber pendapatan menjadi milik masyarakat secara keseluruhan. Hak individu untuk memiliki harta atau memanfaatkan produksi tidak diperbolehkan. b. Kesamaan ekonomi sistem ekonomi sosialis menyatakan, (walaupun sulit ditemui disemua negara komunis) bahwa hak-hak individu dalam suatu bidang ekonomi ditentukan oleh prinsip kesamaan. Setiap individu disediakan kebutuhan hidup menurut keperluan masing-masing. c. Keseluruhan negara diletakkan di bawah peraturan kaum buruh, yang mengambil alih semua aturan produksi dan distribusi. 3 . Kelebihan sistem ekonomi sosialis a. Semua kegiatan ekonomi dikendalikan oleh pemerintah, sehingga pemerintah mudah melakukan control atau pengawasan. b. Tidak ada kesenjangan ekonomi yang mencolok di antara anggota masyarakat. c. Pemerintah mudah dalam mengatur dan melakukan pembentukan harga pasar atas barang dan jasa. 4. Kekurangan sistem ekonomi sosialis a. Melemahkan bahkan mematikan inisiatif dan kreativitas individu. b. Seringnya terjadi prakteik monopoli yang merugikan masyarakat. c. Masyarakat tidak memiliki kebebasan di dalam memiliki sumbersumber daya yang ada.

\section{Sistem Ekonomi Islam}

Ajaran Islam yang berdimensi sosial ekonomi (muamalah) memerlukan pemahaman dan penelitian lebih lanjut, karena aspek muamalah lebih bersifat dinamis dan lentur dalam pengembangan dan penerapan hukumnya dari pada ajaran Islam yang berdimensi ibadah (Tho'in dan Prastiwi, 2015). Dengan demikian, dalam melakukan kegiatan ekonomi harus senantiasa berlandaskan sumber-sumber hukum Islam yang ada, tetapi juga harus berani melakukan tindakan dan pembaharuan dalam melakukan kegiatan ekonomi, agar umat Islam tidak tertinggal dalam hal ekonomi.

Banyak yang menanyakan apakah pada zaman Rasulullah Muhammad SAW dan Sahabat sistem ekonomi yang digunakan saat itu adalah sistem ekonomi Islam? Tentunya hal itu bisa dikatakan benar pula, karena semua aspek kehidupan termasuk masalah ekonomi di dasarkan pada sumber-susmber hukum Islam yang ada, termasuk pada saat itu sudah ada lembaga keuangan Islam yang di sebut baitul maal (Herlina dan Tho'in, 2013). Baitul maal wat tamwil Sebagai sebuah lembaga Koperasi Jasa Keuangan Syariah (KJKS) sekaligus sebagai lembaga intermediasi antara penghimpunan dan penyaluran dana dari dan untuk masyarakat (Tho'in, 2011). Tetapi pada zaman Rasulullah dan sahabat fungsinya tidak sekecil itu tetapi sampai pada pengelolaan kekayaan negara.

Banyak pula yang mengatakan bahwa saat itu belum bisa dikatakan sebagai suatu sistem dalam sistem ekonomi Islam, sebab sistem itu tertata dan harus sistematis sebagai suatu ideologi. Oleh karena itu, yang berpendapat demikian mengatakan bahwasanya sistem ekonomi Islam sampai saat ini hanya baru pada tataran konsep saja dan belum mampu diaplikasikan seperti sistem ekonomi sosialis maupun sistem ekonomi kapitalis.

Ekonomi Islam sebagaimana yang telah dikemukakan oleh Manan (1992), merupakan suatu ilmu pengetahuan sosial yang mempelajarai ilmu ekonomi rakyat yang diilhami oleh nilai-nilai Islam. Sedangkan pengertian yang lain yang JURNAL AKUNTANSI DAN PAJAK VOL. 16 NO. 02, JANUARI 2016 -27 
dikemukakan oleh Halidai, ekonomi Islam merupakan kumpulan dasar-dasar umum ekonomi yang disimpulkan dari al-Qur'an dan sunnah yang ada hubungannya dengan berbagai permasalahan-permasalahan atau persoalan-persoalan ekonomi (Ali, 1988).

Menurut Tho'in (2015), bahwa tantangan besar ekonomi Islam adalah dihadapkan pada dua hal yang sangat besar yaitu "kemiskinan dan kebodohan". Artinya kemiskinan dan kebodohan itu sendiri diyakini atau tidak ternyata menjadi sesuatu yang nyata bagi ummat ini dalam menyelesaikan permasalahan ekonomi ummat.

Oleh karena itu hendaknya sistem ekonomi Islam yang sampai saat ini baru sampai pada tataran konsep harus banyak belajar pula dari kedua sistem ekonomi yang telah ada sebelumnya, yaitu sistem ekonomi kapitalis dan sistem ekonomi sosialis, tentunya mengambil hal-hal yang positif dari keduanya selama tidak bertentangan dengan syariat Islam yang bersumber dari sumber-sumber hukum Islam terutama al-Qur'an dan al-Hadits.

Sistem ekonomi Islam yang baru pada tataran konsep akan dapat berjalan jika mampu memanfaatkan segala sumber daya umat yang ada. Hal itu karena, sumber daya yang dimiliki digunakan maksimal dalam rangka menghadapi perubahan lingkungan (Nuryanto dkk, 2014).

Oleh karena itu, sistem ekonomi Islam ini akan menjadi sistem ekonomi alternatif dalam menciptakan sistem ekonomi yang berkeadilan menuju masyarakat yang makmur dengan banyak pembelajaran juga dari dua sistem ekonomi yang ada, yaitu sistem ekonomi kapitalis dan sistem ekonomi sosialis, tentunya membawa hal-hal positif dari keduanya asalkan tidak bertentangan dengan syariah
Islam yang berasal dari sumber-sumber hukum Islam, khususnya al-Qur'an dan alHadis Rasulullah SAW, agar ekonomi ummat Islam juga dapat berkembang sejalan dengan kemajuan teknologi tetapi masih dalam koridor dan batas-batas agama yang diperbolehkan.

\section{KESIMPULAN}

Berdasarkan pemaparan di atas, bahwa sistem ekonomi sosialis, sistem ekonomi dimana pemerintah memiliki peran yang sangat besar dalam mengelola roda ekonomi dari hulu sampai ke hilir dalam rantai ekonomi di masyarakat, dan sistem ekonomi ini belum ada atau tidak berkembang sejak runtuhnya Uni Soviet. Sementara sistem ekonomi kapitalis, sistem ekonomi memberi orang kebebasan untuk memiliki harta, dan sistem ini juga mendominasi sistem ekonomi yang digunakan oleh negara-negara di dunia ini. Kemudian sistem ekonomi Islam sampai saat ini merupakan konsep yang akan menjadi alternatif bagi sistem ekonomi yang sejahtera dengan banyak pembelajaran juga dari dua sistem ekonomi yang ada, yaitu sistem ekonomi kapitalis dan sistem ekonomi sosialis, tentunya membawa hal-hal positif dari keduanya asalkan tidak bertentangan dengan syariah Islam yang berasal dari sumber-sumber hukum Islam, khususnya al-Qur'an dan alHadis Rasulullah SAW.

\section{DAFTAR PUSTAKA}

Agustiati. (2009). Sistem Ekonomi Kapitalisme, Jurnal Academica, Volume 1 Nomor. 2, Palu: Universitas Tadulako.

Ali, MD. (1988). Sistem Ekonomi Islam Zakat dan Wakaf. Jakarta: UI- Press

Amazine.co-Online Popular Knowledge Tahun 2017.

Asy'arie, Musa, Prof. Dr., Disampaikan JURNAL AKUNTANSI DAN PAJAK VOL. 16 NO. 02, JANUARI 2016 -28 
dalam Focused Group Discussion Matakuliah Sejarah Pemikiran Ekonomi Islam, Pascasarjana (S3 Ekonomi Islam) UIN Sunan Kalijaga, Kamis, 15 Desember 2016.

Boediono, Ekonomi Makro, Seri Sinopsis Pengantar Ilmu EkonomiNo. 2, Edisi, Yogyakarta: BPFE, 1993

Dumatry. (1996). Pengtertian Sistem Ekonomi Menurut Para Ahli. http://ngobrolpikiran.blogspot.co.id/ 2016/01/sitem-ekonomi.html.

Caporaso, A. James. (2008). Teori Teori Ekonomi Politik, Yogyakarta: Pustaka Pelajar.

Chaudhry, Muhammad Sharif. (2012). Sistem Ekonomi Islam, Prinsip Dasar, Jakarta: Kencana.

Gilarso. (1992). Pengantar Ilmu Ekonomi Bagian Makro. Kanisius. Yogyakarta.

Manan, M. A., (1992). Teori dan Praktik Ekonomi Islam.

Nuryanto, R., Tho'in, M., \& Wardani, H. K. (2014). Rasio Likuiditas, Rasio Solvabilitas, Rasio Rentabilitas
Koperasi Jasa Keuangan Syariah Di Jawa Tengah. Jurnal Akuntansi dan Pajak, 15(01).

Tho'in, M. (2011). Pengaruh Faktorfaktor Kualitas Jasa terhadap Kepuasan Nasabah di Baitul Mal Wat Tamwil (BMT) Tekun Karanggede Boyolali. MUQTASID Jurnal Ekonomi dan Perbankan Syariah, 2(1), 73-89.

Tho'in, M., \& Prastiwi, I. E. (2015). Wakaf Tunai Perspektif Syariah. Jurnal Ilmiah Ekonomi Islam, $1(02)$.

Tho'in, M. (2015). Konsep Ekonomi Islam Jalan Tengah (KapitalisSosialis). Jurnal Ilmiah Ekonomi Islam, 1(03).

Wardani, H. K., \& Tho'in, M. (2013). Pengelolaan Baitul Maal Dalam Meningkatkan Kesejahteraan Negara. Jurnal Akuntansi dan Pajak, 14(01).

Winardi. (1990). Ilmu Ekonomi (AspekAspek Sejarahnya. Bandung: PT Citra Aditya Bakti. 